\title{
IMPLEMENTASI PEMBAGIAN HARTA BERSAMA DALAM PERKAWINAN POLIGAMI
}

\author{
Zainul Fanani \\ Kantor Kementerian Agama Kabupaten Malang \\ Email : zainulfanani5@gmail.com
}

\begin{abstract}
Abstrak
Pasal 94 ayat (1) kompilasi Hukum Islam menyebutkan harta bersama dari perkawinan seorang suami yang mempunyai istri lebih dari seorang, masingmasing terpisah dan berdiri sendiri, ayat (2) menyebutkan pemilikan harta bersama dari perkawinan seorang suami yang mempunyai isteri lebih dari seorang dihitung pada saat berlangsungnya akad perkawinan yang kedua, ketiga dan keempat. Dengan demikian momentum pelaksanaan perkawinan merupakan hal yang sangat signifikan dalam penentuan harta bersama dalam perkawinan poligami. Hal ini akan menjadi hambatan dalam pembagian harta bersama, khususnya menyangkut masalah pembuktian harta bersama tersebut
\end{abstract}

Kata kunci: harta Bersama, poligami, pembagian

\begin{abstract}
Article 94 paragraph (1) compilation of Islamic law mentions joint property of marriage of more than one spouse, separate and independent, paragraph (2) mentions the joint ownership of marriage of husband of more than one spouse at the time of the second, third and fourth marriages. Thus the momentum of the marriage exercise is a very important factor in the determination of common property in polygamous marriage. This would be a hindrance in the sharing of common property, especially with regard to the issue of proof of the common property

Keywords: Shared property, polygamy, subdivision
\end{abstract}

\section{PENDAHULUAN}

Fitrah untuk hidup secara berpasangan merupakan satu lumrah kehidupan manusia. Bagi memenuhi dorongan biologi ini umat Islam terikat dengan peraturan perkahwinan yang bertera skan syariat. Perkahwinan bahagia berteraskan kasih sayang dan kemesraan menjadi motivasi dan penggerak ke arah kesempurnaan hidup di dunia dan di akhirat. Sebaliknya perkahwinan yang retak akan menghasilkan masalah masalah ketidakteguhan peribadi yang membawa kesan negatif bukan sahaja kepada diri bahkan juga masyarakat.

Islam adalah agama fitrah yang mengiktiraf berbagai keperluan dan kehendak manusia dalam hidup berpasangan. Berasaskan kepada keadaan inilah Islam membenarkan poligami yang merupakan amalan masyarakat turun temurun sejak sebelum kedatangan Islam lagi. Bagi memastikan amalan poligami secara yang lebih adil dan dapat menjamin kesejahteraan hidup ummat seluruhnya, Islam telah menetapkan syarat-syarat tertentu yang menghadkan amalan yang bebas 


\section{$\mathcal{H}$ urnal Negara dan Keadilan \\ p-ISSN 2302-7010 e-ISSN 2721-9801}

sebelum ini dan mengambil jalan pertengahan yang lebih wajar. Syariat Islam menetapkan bahawa seorang lelaki boleh berkahwin dengan lebih dari seorang perempuan tetapi tidak melebihi empat orang. Poligami merupakan suatu realita hukum dalam masyarakat yang akhir-akhir ini menjadi suatu perbincangan hangat serta menimbulkan pro dan kontra. Poligami sendiri mempunyai arti suatu sistem perkawinan.

Pada dasarnya dalam Undang-Undang No. 1 Tahun 1974 Tentang Perkawinan (selanjutnya disebut Undang-Undang Perkawinan) menganut adanya asas monogami dalam perkawinan. Hal ini disebut dengan tegas dalam Pasal 3 ayat (1) Undang-Undang Perkawinan yang menyebutkan bahwa pada asasnya seorang pria hanya boleh mempunyai seorang istri dan seorang wanita hanya boleh mempunyai seorang suami. Akan tetapi asas monogami dalam UndangUndang Perkawinan tidak bersifat mutlak, artinya hanya bersifat pengarahan pada pembentukan perkawinan monogami dengan jalan mempersempit penggunaan lembaga poligami dan bukan menghapus sama sekali sistem poligami. Ketentuan adanya asas monogami ini bukan hanya bersifat limitatif, karena dalam Pasal 2 ayat (2) Undang. Undang Perkawinan disebutkan, untuk pengadilan dapat memberikan izin pada seorang suami untuk beristri lebih dari seorang apabila dikehendaki oleh pihak yang bersangkutan.

Pernikahan monogami adalah ikatan perkawinan yang hanya membolehkan suami mempunyai satu isteri saja pada jangka waktu tertentu. Sedangkan pernikahan poligami adalah perkawinan seorang laki-laki dengan lebih dari seorang perempuan dalam waktu yang bersamaan. Dari pengertian di atas antara monogami dan poligami terdapat perbedaan yang jelas yaitu pada jumlah isteri yang dimiliki oleh suami, untuk monogami hanya satu isteri saja sedangkan poligami memiliki banyak isteri. Poligami merupakan salah satu masalah atau polemik yang tak akan lekang termakan zaman. Karena persoalan ini sudah ada sejak dulu mulai dari zaman sebelum datangnya Islam sampai zaman modern ini, bahkan poligami dikenal sebagai masalah kemasyarakatan, oleh bangsa-bangsa di permukaan bumi karena masalah ini selalu timbul dalam kehidupan bermasyarakat $^{1}$

Perkawinan menimbulkan hak dan kewajiban suami dan istri yang bersangkutan. Kewajiban disini adalah sesuatu yang harus dilaksanakan atau diadakan oleh suami dan istri, artinya keduanya mempunyai keharusan untuk saling memenuhi kebutuhan lahiriah maupun batiniah. Menurut Hukum Islam, kewajiban istri terdapat dalam Buku I Pasal 77 ayat (2) Kompilasi Hukum Islam Tentang Perkawinan yang menyebutkan bahwa Suami istri wajib saling mencintai, hormat menghormati, setia dan memberi bantuan lahir batin satu kepada yang lain. Akan tetapi ketika kewajiban tersebut tidak terpenuhi lagi maka perasaan ingin medapatkan kebutuhan lahir maupun kebutuhan batin dari luar lingkungan keluarga akan timbul. Seperti halnya yang terjadi di sebagian kalangan masyarakat kita, karena kesibukan akhirnya suami istri kurang memperhatikan waktu untuk bersama, pada akhirnya waktu senggang digunakan

\footnotetext{
${ }^{1}$ A. Tihami dan Sohari Sahrani, Fikih Munakahat Kajian Fikih Nikah Lengkap, Cet. II (Jakarta: Rajawali Pres, 2010), hlm. 35
} 


\section{Zurnal Negara dan $\mathcal{X}$ eadilan \\ p-ISSN 2302-7010 e-ISSN 2721-9801}

untuk mencari pasangan lainnya guna memenuhi kebutuhan lahir batin yang tidak ia dapatkan di rumah, tidak terkecuali seorang suami, dari ketidakpuasan atas kebutuhan yang diberikan oleh pasangan inilah yang menjadi dasar seorang suami mencari pasangan lain di luar lingkungan keluarganya dengan melakukan poligami (mempunyai istri lebih dari satu) guna melengkapi kebutuhan yang tidak terpenuhi dalam keluarganya.

Namun pada praktiknya, awalnya seorang pria kawin dengan seorang wanita seperti layaknya perkawinan monogami, kemudian setelah berkeluarga dalam beberapa tahun pria tersebut kawin lagi dengan istri keduanya tanpa menceraikan isteri pertamanya. Meskipun demikian, sang suami mempunyai alasan atau sebab mengapa ia mempunyai keputusan untuk menikah lagi, karena peristiwa tersebut banyak terjadi di masyarakat, maka muncul beberapa pendapat dan pemahaman terhadap poligami, baik itu datang dari kalangan masyarakat awam maupun di kalangan intelektual. Dimana pada umumnya mereka berpendapat bahwa perkawinan poligami tidak menunjukan keadilan. Oleh sebab itu pemerintah mengeluarkan Undang-undang No.1 Tahun 1974 Tentang Perkawinan. Undang-undang tersebut mengatur asas yang dianutnya, yaitu asas monogami, bahwa baik pria maupun wanita hanya apabila dikehendaki oleh yang bersangkutan karena hukum dan agama yang mengizinkannya, seorang suami dapat beristrikan lebih dari seorang isteri, meskipun hal tersebut dikehendaki oleh pihak-pihak yang bersangkutan, hanya dapat dilakukan apabila memenuhi beberapa persyaratan tertentu dan diputuskan di pengadilan.

Permasalahan yang dapat ditimbulkan perkawinan poligami tersebut ialah apakah perkawinan yang dilakukan oleh suami tersebut sudah sesuai dengan peraturan yang berlaku atau melakukan perkawinan poligami tanpa memenuhi persyaratanyang ada dalam undang-undang tentang perkawinan yang dapat menimbulkan pertanyaan apakah sah atau tidaknya dimata hukum lalu apabila sang suami telah meningal dunia dan meninggalkan harta yaitu harta warisan yang harus dengan segera agar dibagikan kepada ahli waris, bagaimana hak waris atas harta tersebut. Bahwa dalam pembagian harta warisan itu menurut Hukum Islam, yang lebih diutamakan adalah orang yang mempunyai hubungan darah (nasab) dengan pewaris, sesuai dengan Pasal 174 Kompilasi Hukum Islam serta dalam Surat An-Nisa ayat 7, maka isteri dan anak-anaknya sangatlah berperan dalam pembagian harta warisan. Pembagian warisan untuk menikah lebih dari satu kali sering menimbulkan masalah yaitu bagaimana hak waris dari istri atas perkawinan poligami tersebut.

\section{Metode penelitian}

Metode Penelitian

Penelitian adalah usaha secara ilmiah untuk mengetahui atau mempelajari fakta-fakta yang baru dapat diartikan sebagai penyaluran rasa ingin tahu. Penelitian pada dasarnya adalah suatu kegiatan terencana dilakukan dengan 


\section{$\mathcal{H}$ urnal Negara dan Keadilan \\ p-ISSN 2302-7010 e-ISSN 2721-9801}

metode ilmiah bertujuan untuk mendapatkan data baru guna membuktikan kebenaran atau ketidakbenaran dari suatu gejala atau hipotesa yang $\operatorname{ada}^{2}$.

Penelitian hukum merupakan suatu kegiatan ilmiah yang didasarkan pada metode, sistematika dan pemikiran tertentu yang bertujuan untuk mempelajari satu atau beberapa gejala hukum tertentu dengan jalan menganalisanya. Kecuali itu maka juga diadakan pemeriksaan mendalam terhadap fakta hukum tersebut untuk kemudian mengusahakan suatu pemecahan atas permasalahanpermasalahan yang timbul di dalam gejala-gejala yang bersangkutan. ${ }^{3}$

\section{PEMBAHASAN}

Poligami merupakan suatu realitas hukum dalam masyarakat yang akhirakhir ini menjadi suatu perbincangan hangat serta menimbulkan pro dan kontra. Poligami sendiri mempunyai arti suatu sistem perkawinan antara satu orang pria dengan lebih dari seorang istri. Pada dasarnya dalam Undang-Undang Perkawinan No. 1 Tahun 1974 tentang Perkawinan (selanjutnya disebut Undang-Undang Perkawinan) menganut adanya asas monogami dalam perkawinan. Hal ini disebut dengan tegas dalam Pasal 3 ayat (1) Undang-Undang Perkawinan No. 1 Tahun 1974 tentang Perkawinan yang menyebutkan bahwa pada asasnya seorang pria hanya boleh mempunyai seorang istri dan seorang wanita hanya boleh mempunyai seorang suami.

Akan tetapi asas monogami dalam Undang-Undang Perkawinan No. 1 Tahun 1974 tentang Perkawinan tidak bersifat mutlak, artinya hanya bersifat pengarahan pada pembentukan perkawinan monogami dengan jalan mempersulit dan mempersempit penggunaan lembaga poligami dan bukan menghapus sama sekali sistem poligami.

Ketentuan adanya asas monogami ini bukan hanya bersifat limitatif saja, karena dalam Pasal 2 ayat (2) Undang-Undang Perkawinan disebutkan dimana pengadilan dapat memberikan izin pada seorang suami untuk beristri lebih dari seorang apabila dikehendaki oleh para pihak yang bersangkutan. Ketentuan ini membuka kemungkinan seorang suami dapat melakukan poligami dengan ijin pengadilan. Hal ini erat kaitannya dengan berbagai macam agama yang ada yang dianut oleh masyarakat karena ada agama yang melarang untuk berpoligami dan ada agama yang membenarkan atau membolehkan seorang suami untuk melakukan poligami. Khusus yang beragama Islam harus mendapat ijin dari pengadilan agama sesuai dengan Pasal 51 ayat (1) Kompilasi Hukum Islam dan yang beragama selain Islam harus mendapat ijin dari pengadilan negeri. Jadi hal ini tergantung dari agama yang dianut dan pengadilan yang berkompeten untuk itu.

Untuk mendapatkan ijin dari pengadilan harus memenuhi syarat-syarat tertentu disertai dengan alasan yang dapat dibenarkan. Tentang hal ini lebih lanjut diatur dalam Pasal 5 Undang-Undang Perkawinan dan Peraturan Pemerintah Nomor 9 Tahun 1975 tentang Pelaksanaan Undang-Undang Perkawinan No. 1

2. Bambang Waluyo, Penelitian Hukum Dalarn Praktek, (Jakarta: Sinar Grafika, 1991), hal. 2

3 Soerjono Soekanto, Pengantar Penelitian Hukum, Cetakan 2, (Jakarta: Penerbit Universitas Indonesia, 1986), hlm. 21. 


\section{Hurnal Negara dan $\mathcal{X}$ eadilan \\ p-ISSN 2302-7010 e-ISSN 2721-9801}

Tahun 1974 tentang Perkawinan.

Untuk beristri lebih dari satu orang dengan ketentuan jumlah istri dalam waktu yang bersamaan terbatas hanya sampai 4 orang. Adapun syarat utama yang harus dipenuhi adalah suami mampu berlaku adil terhadap istri-istrinya dan anakanaknya, akan tetapi jika si suami tidak bisa memenuhi maka suami dilarang beristri lebih dari satu, di samping itu si suami harus terlebih dahulu mendapat ijin dari pengadilan agama, jika tanpa ijin dari pengadilan agama maka perkawinan tersebut tidak mempunyai kekuatan hukum.

Hukum waris di Indonesia masih bersifat pluralistis karena saat ini berlaku tiga sistem hukum kewarisan, yaitu hukum waris adat, hukum waris Islam, hukum waris perdata. Pertama, hukum waris adat yang berlaku di Indonesia sangat beraneka ragam tergantung pada daerahnya. Dalam kewarisan adat ini ada yang bersifat patrilinial, matrilinial ataupun patrilinial dan matrilinial beralih-alih, danbilateral. Hal ini menunjukkan adanya perbedaan-perbedaan daerah hukum Adat yang satu dengan lainnya berkaitan dengan sistem kekeluargaan dengan jenis serta status harta yang akan diwariskan.

Kedua, hukum waris Islam dirumuskan sebagai perangkat ketentuan hukum yang mengatur pembagian harta kekayaan yang dimiliki seseorang pada waktu ia meninggal dunia. Sumber pokok hukum waris Islam adalah Al-Qur'an dan Hadis Nabi, kemudian ijma' (kesamaan pendapat) dan Qias (analogi). Akibat hukum suami menikah dengan lebih dari satu istri (poligami) secara legal, dan meninggal dunia, maka terdapat perhitungan pembagian harta bersama. Separuh harta bersama yang diperoleh dengan istri pertama dan separuh harta bersama yang diperoleh dengan isteri kedua, dan seterusnya, dan masing-masing terpisah dan tidak ada percampuran harta. Pembagian harta warisan tersebut yaitu sama besarnya antara istri pertama dengan istri kedua, ketiga dan seterusnya terhadap bagian masing- masing. Apabila suami mempunyai anak, maka bagian istri atau istri-istri 1/8. Apabila istrinya ada dua, maka 1/8 dibagi dua menjadi 1/16. Jika suami tidak mempunyai anak maka bagian istri adalah 1/4. Selanjutnya bagian 1/4 tersebut dibagi kepada beberapa orang istri sama banyaknya.

Ketiga, Hukum waris KUHPerdata. Di hubungkan dengan sistem keturunan, maka KUHPerdata menganut sistem keturunan bilateral, dimana setiap orang itu menghubungkan dirinya ke dalam keturunan ayah maupun ibunya, artinya ahli waris berhak mewarisi dari ayah jika ayah meninggal dan berhak mewarisi dari ibu jika ibu meninggal.

Ahli waris dalam Hukum Waris Islam menurut hubungan darah ditentukan Pasal $174 \mathrm{KHI}$, yang terdiri dari keluarga sedarah pewaris yaitu hubungan darah ke bawah dan ke atas. Menurut Pasal $174 \mathrm{KHI}$, ahli waris menurut hubungan perkawinan terdiri dari suami atau istri yang hidup terlama, yang disebut dengan Janda atau Duda.

Adanya perbedaan sistem hukum kewarisan tersebut menyebabkan unsurunsur yang terkandung dalam Hukum Waris mempunyai persamaan danperbedaan. Hukum Waris menurut KUHPerdata, Hukum Waris Islam, danHukum Waris Adat mempunyai persamaan dan perbedaan masing-masing. Hukum Waris menurut KUHPerdata dan Hukum Waris Islam berlaku diseluruh wilayah Indonesia bagi penduduk yang tunduk terhadap kedua hukum tersebut. Sedangkan keberlakuan Hukum Waris Adat mempunyai perbedaan disetiap daerah karena daerah di wilayah Indonesia mempunyai adat yang berbeda. 


\section{Jurnal Negara dan $\mathcal{X}$ eadilan \\ p-ISSN 2302-7010 e-ISSN 2721-9801}

Dalam hukum Islam mengenai harta bersama ini dapat diketahui hanya melalui syirkah, pada dasarnya syirkah ini merupakan konsep yang diterapkan pada hal-hal yang berkaitan dengan perdagangan, sehingga dalam hukum Islam harta bersama minim sekali disinggung.Dalam satu perkawinan, harta bersama dalam perkawinan ini cukup penting peranan dan kemanfaatannya. Akan tetapi bagaimana jika persoalan harta bersama ini terjadi pada kasus poligami Bagaimana cara membagi harta dalam perkawinan tersebut? Berapa bagian untuk istri pertama, kedua, dan seterusnya Serta bagaimana pula jika diantara beberapa istri tersebut ada yang bekerja (mencari nafkah) namun ada pula yang hanya di rumah (ibu rumah tangga)? Apakah dalam hal ini masing-masing istri mendapatkan pembagian yang sama atas harta dalam perkawinan tersebut. Konflik keluarga poligami biasanya meningkat, dan ia harus menyesuaikan pada dua atau lebih ragam kehidupan keluarga, dan menghadapi tiga atau lebih unit keluarga besar. Sementara itu bagi istri pertama, poligami yang dilakukan oleh suaminya umumnya menjadi peristiwa traumatis. Ia akan mempertanyakan pada dirinya "saya ini siapa sekarang", kehilangan identitas yang telah diembannya selama bertahun-tahun. Reaksi-reaksi seperti marah, kecewa, merasa dikhianati, dan menjadi bingung akan dialaminya,Selain mengalami pengingkaran komitmen perkawinan, istri pertama juga mengalami tekanan psikologis, ekonomi, seksual, fisik, hingga pandangan iba dan sinis dari masyarakat. Di samping kondisi sosial ekonomi yang tidak merata yang menjadikan lebih berfikir materil, sehingga adanya konflik kepentingan yang didasari oleh motif ekonomi mengarahkan untuk memilih hukum kewarisan yang berpihak kepada kepentingan dirinya. Hal ini akan berpengaruh terhadap efektifitas hukum waris Islam yang berlaku di tengahtengah keluarga tersebut.

Pengadilan agama baru dapat memberikan ijin kepada suami untuk berpoligami apabila ada alasan yang tercantum dalam Pasal 4 ayat (2) UndangUndang Perkawinan:

1. Istri tidak dapat menjalankan kewajiban sebagai istri

2. Istri mendapat cacat badan atau penyakit yang tidak dapat disembuhkan

3. Istri tidak dapat melahirkan keturunan

Di samping syarat-syarat tersebut yang merupakan alasan untuk dapat mengajukan poligami juga harus dipenuhi syarat-syarat menurut Pasal 5 ayat (1) Undang-Undang Perkawinan, yaitu :

1. Adanya persetujuan dari istri

2. Ada kepastian bahwa suami mampu menjamin keperluan hidup istri dan anak-anaknya

3. Ada jaminan bahwa suami berlaku adil terhadap para istri dan anakanaknya.

Mengenai persyaratan persetujuan dari istri yang menyetujui suaminya poligami dapat diberikan secara tertulis atau secara lisan akan tetapi sekalipun telah ada persetujuan tertulis dari istri persetujuan ini harus dipertegas dengan persetujuan lisan dari istri pada sidang pengadillan agama. Persetujuan dari istri yang dimaksudkan tidak diperlukan bagi suami apabila istri atau istri-istrinya tidak mungkin dimintai persetujuan dan tidak mungkin menjadi pihak dalam perjanjian dan apabila tidak ada khabar dari istrinya selama sekurang-kurangnya 2 tahun atau karena sebab-sebab lainnya yang mendapat penilaian dari hakim Pengadilan Agama. 


\section{Hurnal Negara dan $\mathcal{X}$ eadilan \\ p-ISSN 2302-7010 e-ISSN 2721-9801}

Pada asasnya dalam suatu perkawinan seorang pria hanya boleh mempunyai seorang istri, begitu juga dengan seorang wanita, namun dalam keadan tertentu lembaga perkawinan yang berasaskan monogami sulit dipertahankan.sehingga dalam keadaan yang sangat terpaksa dimungkinkan seorang laki-laki memiliki istri lebih dari seorang berdasarkan syarat-syarat yang telah ditentukan oleh Undang-Undang Perkawinan. Pasal 35 Undang-Undang Perkawinan mengatur tentang harta benda dalam perkawinan yaitu harta benda yang diperoleh selama perkawinan berlangsung menjadi harta bersama. Pasal 37 Undang-Undang Perkawinan menyatakan bila perkawinan putus karena perceraian, harta bersama diatur menurut hukumnya masing-masing, sedangkan di dalam Kompilasi Hukum Islam diatur apabila perkawinan putus karena perceraian, harta bersama dibagi antara suaml istri dengan pembagian yang sama. Dalam hal seorang laki-laki yang memiliki istri lebih dari seorang maka akan timbul suatu sengketa mengenai harta bersama tersebut, sehingga diperlukanlah suatu aturan yang jelas mengenai pembagian harta tersebut

Harta bersama dari perkawinan seorang suami yang mempunyai istri lebih dari seorang, masing-masing terpisah dan berdiri sendiri. Pemilikan harta bersama dalam perkawinan poligami dihitung pada saat berlangsungnya akad perkawinan yang kedua, ketiga, atau yang keempat. Istri pertama dari suami yang berpoligami mempunyai hak atas harta gono-gini yang dimilikinya bersama dengan suaminya. Istri kedua dan seterusnya berhak atas harta gono-gininya bersama dengan suaminya sejak perkawinan mereka berlangsung. Kesemua istri memiliki hak yang sama atas harta gono-gini tersebut. Namun, istri istri yang kedua dan seterusnya tidak berhak terhadap harta gono-gini istri yang pertama. Pembagian harta bersama dalam perkawinan poligamu untuk kasus cerai mati dibagi menjadi 50 : 50. Berdasarkan Pasal 97 KHI dinyatakan bahwa, janda atau duda cerai hidup masingmasing berhak seperdua dari harta bersama sepanjang tidak ditentukan lain dalam perjanjian perkawinan.

\section{PENUTUP}

Pasal 86 Kompilasi Hukum Islam menyebutkan bahwa pada prinsipnya tidak ada percampuran harta suami dan istri karena perkawinan. Suatu harta dikatakan rsama apabila harta tersebut diperoleh dalam perkawinan, tanpa mempersoalkan terdaftar atas nama suami atau istri. Lebih lanjut Pasal 94 ayat (1) kompilasi Hukum Islam menyebutkan harta bersama dari perkawinan seorang suami yang mempunyai istri lebih dari seorang, masing-masing terpisah dan berdiri sendiri, ayat (2) menyebutkan pemilikan harta bersama dari perkawinan seorang suami yang mempunyai isteri lebih dari seorang dihitung pada saat berlangsungnya akad perkawinan yang kedua, ketiga dan keempat. Dengan demikian momentum pelaksanaan perkawinan merupakan hal yang sangat signifikan dalam penentuan harta bersama dalam perkawinan poligami. Hal ini akan menjadi hambatan dalam pembagian harta bersama, khususnya menyangkut masalah pembuktian harta bersama tersebut. Hal ini dapat terjadi apabila penentuan harta bersama dalam perkawinan poligami semata-mata disandarkan pada ketentuan Pasal 94 di atas. 


\section{Jurnal Negara dan Xeadilan \\ p-ISSN 2302-7010 e-ISSN 2721-9801}

\section{DAFTAR PUSTAKA}

A. Tihami dan Sohari Sahrani, 2010, Fikih Munakahat Kajian Fikih Nikah Lengkap, Cet. II Jakarta: Rajawali Pres.

Bambang Waluyo, 1981, Penelitian Hukum Dalarn Praktek, Jakarta: Sinar Grafika.

Soerjono Soekanto, 1986, Pengantar Penelitian Hukum, Cetakan 2, Jakarta: Penerbit Universitas Indonesia. 